\title{
Pengembangan Buku Ajar Matematika Ekonomi Berbasis Problem Based Learning yang Mendukung Kemampuan HOTS Mahasiswa
}

\author{
Zaimi Effendi ${ }^{1}$, Novferma ${ }^{2}$, dan Evtita $^{3}$ \\ ${ }^{1,2,3}$ Prodi Pendidikan Matematika, Universitas Jambi \\ Email: ${ }^{1}$ zaimieffendi@yahoo.com, ${ }^{2}$ novfermaa@gmail.com, ${ }^{3}$ evtita@gmail.com
}

\begin{abstract}
Abstrak
Penelitian ini bertujuan untuk menghasilkan dan mendeskripsikan kualitas buku ajar matematika ekonomi berbasis problem based learning mendukung kemampuan HOTS mahasiswa berdasarkan kriteria valid, praktis, dan efektif. Model pengembangan yang digunakan dalam penelitian ini yaitu model Four-D (4-D) yang terdiri dari empat tahap yaitu definisi, desain, pengembangan, dan penyebaran. Subjek ujicoba terbatas adalah satu orang dosen dan 20 mahasiswa pendidikan matematika FKIP Universitas Jambi.Sedangkan subjek uji coba lapangan dilakukan pada satu kelas yaitu kelas mahasiswa regular di prodi pendidikan matematika, tahun pelajaran 2016/2017. Hasil penelitian menunjukkan bahwa buku ajar dan intrumen penelitian memenuhi kriteria valid. Hal ini dapat ditunjukkan dari presentasi skor rata-rata penilaian ahli untuk buku ajar matematika ekonomi yaitu sebesar $84,3 \%$, sedangkan persentasi skor rata-rata untuk instrumen penelitian yaitu sebesar $82,8 \%$. Buku ajarpenelitian memenuhi kriteria kepraktisan berdasarkan penilaian oleh dosen yang termasuk dalam kategori baik.Buku ajar dan instrument penelitian memenuhi kriteria keefektifan berdasarkan hasil uji coba lembar observasi aktivitas mahasiswa yang memenuhi kriteria baik yaitu $85,6 \%$, hasil tes higher order thingking skills sebesar $84,2 \%$, dan respon mahasiswa positif sebesar $85,4 \%$. Berdasarkan hasil yang disebutkan diatas maka produk berupa Buku ajar matematika ekonomi pembelajaran yang dikembangkan telah memenuhi kriteria valid, praktis, dan efektif, sehingga layak untuk digunakan.
\end{abstract}

Kata Kunci: Pengembangan, Buku Ajar,Matematika Ekonomi,Problem Based Learning, dan Higher Order Thingking Skills (HOTS).

\section{Development of Economic Mathematics Textbook Based on Problem Based Learning that Supports Students HOTS Ability}

\begin{abstract}
This research aims to produce and describe the quality of problem-based learning based economics mathematics textbooks supporting the ability of HOTS students based on valid, practical, and effective criteria. The development model used in this study is the Four-D (4-D) model which consists of four stages, namely definition, design, development, and dissemination. The subject of limited trials was one lecturer and 20 mathematics education students from the FKIP Jambi University. While the subject of field trials was conducted in one class, namely the regular student class in the mathematics education program, 2016/2017 school year. The results show that textbooks and research instruments meet valid criteria. This can be shown from the presentation of the average score of the expert assessment for the economic mathematics textbook that is equal to $84.3 \%$, while the percentage of the average score for the research instrument is $82.8 \%$. The research textbook fulfills the practicality criteria based on the assessment by the lecturers who are in the good category. Textbooks and research instruments meet the criteria of effectiveness based on the results of the observation sheet of the activity of students who meet good criteria of $85.6 \%$, the results of higher order tests thingking skills are $84.2 \%$, and positive student responses are $85.4 \%$. Based on the results mentioned above, the product in the form of a learning economics mathematics textbook developed has met the criteria of valid, practical, and effective, so that it is suitable for use.

Keywords: Development, Textbooks, Mathematical Economics, Problem Based Learning, and Higher Order Thingking Skills (HOTS).
\end{abstract}




\section{PENDAHULUAN}

Matematika merupakan salah satu bidang studi umum yang diajarkan di jenjang pendidikan tingkat sekolah dasar sampai perguruan tinggi.Matematika adalah ilmu yang sangat berpengaruh dalam perkembangan baik dari teknologi sederhana sampai teknologi modern. Hal ini sesuai dengan lampiran III Permendikbud No.58 tahun 2014 yang menyatakan bahwa matematika merupakan ilmu universal yang berguna bagi kehidupan manusia dan juga mendasari perkembangan teknologi modern, serta mempunyai peran penting dalam berbagai disiplin dan memajukan daya pikir manusia. Untuk menguasai dan mencipta teknologi di masa depan, diperlukan penguasaan dan pemahaman atas matematika yang kuat sejak dini. Serta mata pelajaran matematika perlu diberikan kepada semua peserta didik mulai dari sekolah dasar, untuk membekali peserta didik dengan kemampuan berpikir logis, analitis, sistematis, kritis, inovatif dan kreatif, serta kemampuan bekerja sama.

Kemampuan yang harus dimiliki mahasiswa adalah kemampuan berpikir tingkat tinggi.Berdasarkan silabus dan deskripsi mata kuliah program studi pendidikan matematika bahwa pada mata kuliah matematika ekonomi menuntut mahasiswa untuk berpikir secara kritis, kreatif, logis dalam menemukan solusi penyelesaian permasalahan nyata.Dimana isi dari mata kuliah matematika ekonomi yaitu terdiri dari relasi dan fungsi, fungsi linear dan persamaan garis lurus serta aplikasinya dalam ekonomi yang berkaitan dengan permasalahan nyata.Maka penelitian ini lebih menekankan pada pengembangan kemampuan higher order thinking skills (HOTS) mahasiswa agar tujuan dari mata kuliah matematika ekonomi dapat tercapai dengan baik. Dimana kemampuan Higher order thinking skills (HOTS) merupakan kemampuan berpikir yang terdiri dari komponen berpikir kritis dan berpikir kreatif (Conklin, 2012: 14). HOTS merupakan aspek penting dikembangkan dalam pembelajaran matematika terutama pada perguruan tinggi karena dalam penyelesaian permasalahan nyata yang tidak rutin mahasiswa memerlukan kemampuan berpikir kritis dan kreatif.Hal tersebut sesuai dengan pendapat Brookhart (2010: 6) yang menyebutkan bahwa tujuan pembelajaran yang mengembangkan HOTS adalah untuk membekali mahasiswa terampil memberi alasan dan membuat keputusan. Hal tersebut juga sama dengan hasil penelitian yang dilakukan oleh Farren (2012) yang menyatakan bahwa saat peserta didik memiliki HOTS, mereka terlibat secara mandiri dalam mengambil tanggung jawab serta akuntabilitas atas tindakan yang dilakukan, sedangkan hasil penelitian yang dilakukan oleh Widodo \& Kadarwati (2013) bahwa HOTS dapat meningkatkan aktivitas dan karakter yang kemudian juga dapat meningkatkan hasil belajar peserta didik.

Akan tetapi pada kenyataannya bahwa higher order thingking skills (HOTS) mahasiswa dalam belajar matematika masih rendah. Salah satunya data hasil survei yang dilakukan oleh TIMSS (Trends International Mathematics and Science Study) tahun 2011. Data hasil survei tersebut pada mata pelajaran matematika yang ditinjau dari tiga aspek, yaitu: pengetahuan, aplikasi, dan penalaran seperti pada tabel 1 sebagai berikut (Mulis, Martin, Foy, \& Arora, 2011:150). 
Tabel 1. Rata-rata Skor Indonesia Berdasarkan Data TIMSS Tahun 2011

\begin{tabular}{llccc}
\hline $\begin{array}{l}\text { No } \\
\text { Urut }\end{array}$ & $\begin{array}{l}\text { Kategori } \\
\text { Kemampuan }\end{array}$ & $\begin{array}{l}\text { Rata-Rata } \\
\text { Skor }\end{array}$ & $\begin{array}{l}\text { Skor } \\
\text { Maksimum }\end{array}$ & $\begin{array}{l}\text { Skor } \\
\text { Minimum }\end{array}$ \\
\hline \multirow{3}{*}{38} & Knowing & 378 & 616 & 331 \\
\cline { 2 - 5 } & Applying & 384 & 617 & 316 \\
\cline { 2 - 5 } & Reasoning & 388 & 612 & 322 \\
\hline
\end{tabular}

Sumber: Data TIMSS 2011

Hal tersebut menunjukkan bahwa dalam pembelajaran matematika di kelas kebanyakan guru/dosen belum menekankan pada kemampuan higher order thingking skills (HOTS), sehingga tujuan dari pembelajaran matematika masih terfokus pada hafalan serta pada penerapan konsep saja.Berdasarkan hasil survei awal yang di lakukan di Sekolah (Universiats Jambi), dengan memberikan 3 soal yang mengukur HOTS pada matakuliah matematika ekonomi diperoleh bahwa keterampilan mahasiswa perlu ditingkatkan. Hasil dari analisis tersebut menunjukkan bahwa rata-rata mahasiswa belum dapat menjawab soal yang diberikan dengan benar, sehingga masih perlunya dilakukan peningkatan pembelajaran matematika yang berfokus pada pengembangan higher order thingking skills (HOTS) mahasiswa.

Pembelajaran matematika sangat erat kaitannya dengan proses pembelajaran dan keberhasilan atau target pembelajaran. Dimana sebelum melaksanakan kegiatan pembelajaran perlu adanya perencanaan. Moore (2009: 94) menyatakan bahwa perencanaan dalam setiap pembelajaran memegang peran penting, proses perencanaan akan mempengaruhi keberhasilan mahasiswa dalam memperoleh pengetahuan, sikap, nilai-nilai, dan keterampilan. Hal ini menunjukkan bahwa dalam mencapai pembelajaran yang efektif diperlukan perencanaan yang sistematis.Perencanaan tersebut dapat disusun dan dituangkan dalam bahan ajar.Menurut Depdiknas (2008: 7) bahwa bahan ajar merupakan seperangkat materi yang disusun secara sistematis sehingga tercipta lingkungan/suasana yang memungkinkan peserta didik untuk belajar. Bentuk bahan ajar meliputi: 1) bahan cetak; 2) Audio; 3) Visual; 4) Audio Visual; 5) Multi media. Bahan ajar yang dimaksud dalam penelitian ini adalah buku ajar, dimana buku ajar merupakan salah satu jenis dari bahan ajar.Buku ajar yang dikembangkan sesuai dengan kebutuhan dan karakteristik mahasiswa. Buku ajar yang dikembangkan sebagai alat bantu agar mahasiswa melakukan pengalaman belajar pada proses pembelajaran tatap muka dengan pendidik/dosen maupun pada proses belajar mandiri.

Oleh karena itu, pengembangan buku ajar tersebut hendaknya menggunakan model pembelajaran yang tepat dan sesuai dengan tujuan pembelajaran yang ingin dicapai.Model pembelajaran yang digunakan harus lah membuat mahasiswa terbiasa untuk berpikir secara kreatif, kritis, dalam menemukan solusi penyelesaian permasalahan nyata.Kemampuan berpikir mahasiswa dalam menemuan solusi tersebut diidentifikasikan dapat meningkatkan HOTS mahasiswa. Sehingga model pembelajaran yang sesuai untuk mendukung kemampuan (HOTS) mahasiswa adalahmodel Problem Based Learning. Dimana Problem Based Learning merupakan pembelajaran yang menekankan pada penggunaan masalah sebagai sarana bagi mahasiswa untuk mengembangkan keterampilan berpikir kritis dan kreatif dalam menyelesaikan masalah nyata. Fogarty (2010:2) menyatakan bahwa "problem based learning is a curiculum model designed around real-life. Problems that are ill-structured, open-ended, or ambiguous". Maknanya adalah problem based learning diartikan sebagai model kurikulum 
yang dirancang menggunakan masalah kehidupan nyata. masalah tersebut berupa masalah tidak terstruktur, masalah bersifat terbuka.

Berdasarkan uraian latar belakang diatas, adapun tujuan dari penelitian ini adalah untuk menghasilkan dan mendeskripsikan kualitas buku ajar matematika ekonomi berbasis problem based learning yang mendukung kemampuan higher order thinking skills mahasiswa berdasarkan kriteria valid, praktis, dan efektif"

\section{METODE}

\section{A. Model Pengembangan}

Model pengembangan yang digunakan dalam mendesain buku ajar matematika ekonomi dengan menggunakan Problem Based Learning (PBL) pada matakuliah matematika ekonomi yaitu bagian dari penelitian pengembangan yang menggunakanmodel pengembangan Four- $D$ (4-D) yang dikembangkan oleh Thiagarajan, Semmel, \& Semmel. Pengembangan model 4-D yang digunakan dalam penelitian ini memuat empat tahap yaitu definisi (define), desain (design), pengembangan (develop), dan penyebaran (disseminate). Adapun langkah-langkah pengembangan dijabarkan dalam diagram berikut:

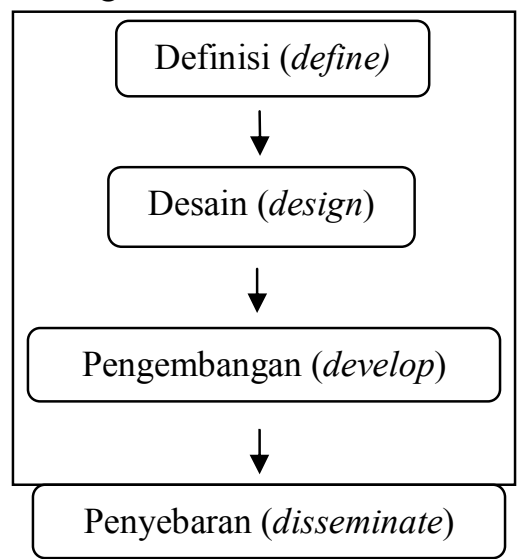

Gambar 1. Tahapan model pengembangan Four-D

\section{B. Prosedur Pengembangan}

Langkah-langkah yang ditempuh dalam prosedur pengembangan dengan model 4-D adalah sebagai berikut:

\section{Tahap Pendefinisian (Define)}

a. Analisis Awal-Akhir

Analisis ini dilakukan untuk mengetahui masalah dasar dalam pengembangan Buku ajar matematika ekonomi pembelajaran menggunakan model Problem Based Learning (PBL).

b. Analisis Karakteristik Mahasiswa

Analisis ini dilakukan dengan menelaah karakteristik mahasiswa.Karakteristik ini meliputi kemampuan, latar belakang pengetahun, dan perkembangan kognitif mahasiswa.

c. Analisis Konsep matakuliah yang akan diajarkan kepada mahasiswa adalah matakuliah matematika ekonomi. 


\section{d. Analisis Tugas}

Analisis ini dilakukan untuk mendapatkan rincian mengenai tugas-tugas yang akan diberikan kepada mahasiswa dalam pembelajaran.

e. Analisis Tujuan Pembelajaran

Analisis tujuan pembelajaran bertujuan untuk mengidentifikasi indikator-indikator ketercapaian hasil belajar mahasiswa (kemampuan higher order thingking skills) berdasarkan kompetensi dasar yang akan dijadikan dasar dalam penyusunan tes.

\section{Tahap Perancangan (Design)}

a. Mengkonstruksi Tes Acuan Kriteria

Tes yang dimaksud pada tahap ini adalah tes untuk mengukur kemampuan higher order thingking skillsmahasiswa yang disusun berdasarkan acuan kriteria yang telah dijabarkan kedalam indikator-indikator pencapaian.

b. Pemilihan media

Pemilihan media berkaiatan dengan penentuan media yang tepat untuk menyajikan materi pembelajaran yang didasarkan pada analisis materi, analisis tugas, dan fasilitas serta karakteristik mahasiswa.

c. Pemilihan format

Langkah ini meliputi kegiatan pemilihan format untuk merancang isi materi, pemilihan strategi, pendekatan, dan metode pembelajaran, serta sumber belajar yang dikembangkan.

d. Perancangan Awal

Perancangan awal dilakukan untuk mendesain buku ajar matematika ekonomi pembelajaran dari hasil analisis yang telah dilakukan pada tahap pendefinisian dan berdasarkan kriteria yang ditentukan dengan media dan format yang sesuai. Hasil rancangan awal ini adalah draft 1 .

\section{Tahap Pengembangan (Develop)}

Tujuan tahap ini adalah untuk menghasikan buku ajar matematika ekonomi pembelajaran yang valid, praktis dan efektif, yang mendukung kemampuan higher oerder thingking skillsmahasiswa.Pada tahap ini dilakukan uji ahli, kegiatan ini dilakukan untuk memperoleh penilaian atau menguji validitas desain awal buku ajar matematika ekonomi pembelajaran dan instrumen penilaian (draft1) dari para ahli terhadap produk yang dikembangkan.buku ajar matematika ekonomi pembelajaran dan instrumen yang telah direvisi berdasarkan masukan dan saran perbaikan dari para ahli ini maka kemudian disebut draft 2 .

\section{Tekhnik Analisis Data}

Data yang berupa komentar, saran, revisi, dan hasil observasi selama proses ujicoba dianalisis secara deskriptif kualitatif dan disimpulkan sebagai masukkan untuk merevisi produk yang dikembangkan.

a. Teknik Analisis Data Kevalidan

Instrumen penilaian kevalidan berupa buku ajar matematika ekonomi, dan instrumen penilaian (kognitif, keterampilan) oleh ahli menggunakan dua skala yaitu, valid dan tidak valid. Langkah-langkah yang digunakan adalah sebagai berikut:

1) Data berupa skor yang diperoleh dari para ahli melalui lembar validasi dijumlahkan.

2) Total skor yang diperoleh kemudian dikonversikan menjadi data kualitatif. 


\section{b. Teknik Analisis Data Kepraktisan}

Data kepraktisan buku ajar matematika ekonomi pembelajaran terdiri data hasil penilaian dan kelayakan penggunaan dikelas.Hal ini diakibatkan karena masing-masing lembar penilaian dan instrumen penilaian untuk dosen mempunyai banyak butir yang berbeda pada setiap lembar penilaian.

1) Analisis data kepraktisan oleh dosen, data nilai yang diperoleh dari dosen penilai kemudian dikumpulkan berdasarkan produk yang dikembangkan. Analisis dilanjutkan dengan menentukan rata-rata akhir dari data yang diperoleh dan menentukan kategori produk sesuai dengan kriteria kepraktisan.

2) Analisis data kepraktisan oleh mahasiswa, analisis data penilaian kepraktisan buku ajar matematika ekonomi oleh mahasiswa dilakukan dengan menghitung rata-rata skor penilaian dari mahasiswa setelah selesai ujicoba lapangan, kemudian mengonversi kedalam data kualitatif.

c. Teknik Analisis Data Keefektifan

Keefektifan menunjukkan ketercapaian tujuan pembelajaran yang akan dicapai dalam suatu pembelajaran apakah sudah sesuai dengan indikator yang telah dijabarkan.

1) Aspek Kognitif

buku ajar matematika ekonomi dikatakan efektif jika ketuntasan klasikal penilaian pengetahuan paling sedikit $70 \%$. Semakin tinggi nilai reliabilitasnya, semakin akurat dan semakin baik tes itu digunakan untuk melakukan pengukuran dengan instrumen yang sama. Nilai Reliabilitas tes yang dibuat umumnya mempunyai nilai diantara 0.60 dan 0,85(Miller, Linn, \& Gronlund, 2009: 107).

Adapun rumus Cronbach's Alpha adalah sebagai berikut:

$$
\mathrm{r}_{11}=\frac{k}{k-1}\left[1-\frac{\sum \sigma_{b}^{2}}{\sigma_{t}^{2}}\right] \sigma^{2}=\frac{\sum X^{2}-\frac{\sum X^{2}}{N}}{N}
$$

Keterangan: $\mathrm{r}_{11}$ : reliabilitas instrument, $\mathrm{k}$ : banyaknya butir soal

$\sum \sigma_{b}^{2} \quad$ : jumlah varians butir, $X$ : Skor setiap butir tes, $N$ : banyaknya subjek, $\sigma_{t}^{2}$ : varians total.

\section{HASIL DAN PEMBAHASAN}

Hasil

\section{A. Proses Pengembangan}

Sebelum mengembangkan bahan ajar, terlebih dahulu peneliti melakukan pendefinisian (define) untuk menentukan tujuan dan permasalahan yang sebagai patokan dalam menyusun bahan ajar yang dibuat. Dalam tahap ini ada beberapa hal yang dilakukan, yaitu (1) analisis Awal-Akhir, (2) Analisis mahasiswa, (3) Analisis Konsep (Materi), (4) Analisis Tugas, (5) merumuskan tujuan pembelajaran. Sedangkan pada tahap perancangan (design) meliputi: (1) Mengkonstruksi tes kriteria acuan, (2) Pemilihan Media, (3) Pemilihan Format, (4) Rancangan Awal.Tahapan selanjutnya adalah tahap pengembangan yaitu merancang prototipe awal dari bahan ajar. Menentukan komponenkomponen dalam penyusun buku ajar matematika ekonomi yang akan dirancang. Tahapan 
terakhir yaitu tahap penilaian.Kegiatan yang dilakukan pada tahap penilaian adalah validasi dan uji coba. Validasi bertujuan untuk menilai kelayakan produk pengembangan yang akan diujicobakan. Uji coba dilaksanakan terdiri dari uji coba kelompok kecil dan uji coba kelompok besar.Uji coba kelompok kecil dilakukan pada 20 orang mahasiswa, Sedangkan uji coba kelompok besar dilakukan pada 38 mahasiswa yang ngontrak matakuliah matematika ekonomi.

\section{B. Hasil Pengembangan}

\section{Data Hasil Validasi Ahli}

Hasil validasi buku ajar matematika ekonomi dan instrumen memenuhi kriteria valid. Adapun hasil validasi tersebut secara rinci disajikan pada tabel 2 dibawah ini:

Tabel 2. Hasil Validasi Buku Ajar Matematika EkonomiDan Intrumen Penelitian

\begin{tabular}{llll}
\hline No & Perangkat dan instrumen & Hasil validasi & $\begin{array}{l}\text { Arti } \\
\text { Kriteria }\end{array}$ \\
\hline 1. & Buku Ajar Matematika Ekonomi & $84,3 \%$ & Valid \\
\hline 2. & Lembar observasi aktivitas dosen & $83,5 \%$ & Valid \\
\hline 3. & $\begin{array}{l}\text { Lembar observasi aktivitas } \\
\text { mahasiswa }\end{array}$ & $82 \%$ & Valid \\
\hline 4. & Penilaian HOTS & $81 \%$ & Valid \\
\hline 5. & Angket respon mahasiswa & $82,5 \%$ & Valid \\
\hline
\end{tabular}

Tabel 2 di atas menunjukkan bahwa dari penilaian ahli terhadap bahan ajar dan instrumen penelitian dapat disimpulkan bahwa buku ajar matematika ekonomi dan instrumen yang dikembangkan secara umum pada kategori valid.

\section{Hasil Uji Coba}

Uji coba produk ini bertujuan untuk menilai kepraktisan dan keefektifan buku ajar matematika ekonomi.buku ajar matematika ekonomi pembelajaran dikatakan praktis, apabila ahli pendidikan dan dosen menyatakan bahwa buku ajar matematika ekonomi pembelajaran dapat diterapkan dalam proses pembelajaran dan tingkat keterlaksanaan buku ajar matematika ekonomi pembelajaran memenuhi kriteria baik.

Tabel 3. Hasil Uji Coba Bahan Ajar Dan Intrumen Penelitian

\begin{tabular}{lc}
\hline Kriteria bahan ajar & Hasil Uji Coba \\
\hline Praktis & Hasil uji coba kelompok kecil terhadap keterlaksanaan \\
& buku ajar matematika ekonomi pembelajaran yaitu \\
& sebesar 95\%. Sedangkan Hasil uji coba kelompok kecil \\
& terhadap instrumen penilaian HOTS yaitu sebesar \\
& $84,22 \%$. Berdasarkan kriteria yang ditetapkan, tingkat \\
& keterlaksanaan buku ajar matematika ekonomi \\
& memenuhi kriteria baik. \\
\hline Efektif & a. Hasil uji lembar observasi aktivitas mahasiswa yang \\
& memenuhi kriteria baik, dengan persentase $85,6 \%$. \\
b. Hasil uji coba Tes Penguasaan HOTS telah memenuhi & kriteria ketuntasan klasikal yakni, 84,2\%. \\
c. Respon mahasiswa kategori positif yaitu sebesar \\
\\
$85,4 \%$.
\end{tabular}


Buku ajar matematika ekonomi pembelajaran dikatakan efektif bila, (1) hasil observasi aktivitas mahasiswa telah memenuhi kriteria baik atau sangat baik, yaitu skor rata-rata hasil observasi mencapai lebih dari atau sama dengan $80 \%$, (2) secara klasikal minimal $80 \%$ dari jumlah peserta tes HOTS mencapai skor lebih dari atau sama dengan 70 , (3) respon mahasiswa positif yaitu persentase mahasiswa yang memberikan respon positif lebih besar atau sama dengan $80 \%$. Adapun hasil uji coba tersebut disajikan pada tabel 3 .

\section{Pembahasan}

Pengembangan buku ajar matematika ekonomi pembelajaran dengan menggunakan model Higher Order Thingking Skills(HOTS)pada matakuliah matematika ekonomi telah mampu mengubah proses pembelajaran matematika. Proses pembelajaran matematika yang cenderung didominasi dosen dan ketidak aktifan mahasiswadalam pembelajaran berjalan dua arah, dimana mahasiswaaktif terlibat dalam setiap kegiatan pembelajaran.

Bahan ajar yang dirancang juga mendukung kemampuan kognitif mahasiswa, yaitu Higher Order Thingking Skills (HOTS) mahasiswa.Buku ajar matematika ekonomi yang dikembangkan harus memenuhi kriteria valid, hal ini dimaksudkan untuk menjamin buku ajar matematika ekonomi tersebut mempunyai validitas isi dan konstruksi. Persentase rataan skor hasil validasi (SV) dari kedua validator untukbuku ajar matematika ekonomi pembelajaran yaitu sebesar $83,5 \%$. Persentase $83,5 \%$ berarti Buku ajar matematika ekonomi pembelajaran menggunakan model problem based learning (PBL) memenuhi kriteria valid. Persentase rataan skor hasil validasi (SV) untuk lembar observasi aktivitas dosen, lembar observasi aktivitas mahasiswa, Tes kemampuan higher order thingking skills, dan Angket respon mahasiswayaitu masing-masing sebesar $83,5 \%, 82 \%, 81 \%$, dan $82,5 \%$. Artinya presentase rataan skor hasil validasi (SV) instrument tersebut memenuhi kriteria valid.

Buku ajar matematika ekonomi dan instrument juga harus memenuhi kriteria praktis dan efektif. Hasil uji coba lapangan menunjukkan bahwa pada uji coba kelompok kecil diperoleh persentase skor rata-rata lembar observasi aktivitas dosen yaitu 82,2\%. Sedangkan pada uji coba kelompok besar diperoleh persentase skor rata-rata lembar observasi aktivitas dosen yaitu 85,6\%. Dari presentase diatas dapat disimpulkan bahwa tingkat keterlaksanaan Buku ajar matematika ekonomi pembelajaran telah memenuhi kriteria baik.Sehingga, Buku ajar matematika ekonomi pembelajaran menggunakan model Problem Based Learning memenuhi kriteria praktis. Sedangkan pembelajaran dikatakan efektif apabila:

(a) Kriteria yang ditetapkan: hasil observasi aktivitas mahasiswa telah memenuhi kriteria baik atau sangat baik, yaitu skor rata-rata hasil observasi mencapai lebih dari atau sama dengan $80 \%$. Hasil uji coba, pada uji coba kelompok kecil diperoleh skor rata-rata hasil observasi lembar observasi aktivitas mahasiswa yaitu 82,2\% Sedangkan, pada uji coba kelompok besar diperoleh skor rata-rata hasil observasi lembar observasi aktivitas mahasiswa yaitu $85,6 \%$. Dari hasil presentase di atas bahwa hasil uji coba lembar observasi aktivitas mahasiswa telah memenuhi kriteria baik.

(b) Kriteria yang ditetapkan : secara klasikal minimal 80\% dari jumlah peserta tes higher order thingking skills mencapai skor lebih dari atau sama dengan 70 . Hasil uji coba diperoleh persentase ketuntasan klasikal tes higher order thingking skills pada uji coba kelompok kecil yaitu 93,3\%, sedangkan persentase ketuntasan klasikal tes higher order 
thingking skills pada uji coba kelompok besar yaitu $84,2 \%$. Sehingga hasil uji coba diperoleh tes higher order thingking skills telah memenuhi kriteria yang ditetapkan.

(c) Kriteria yang ditetapkan: Respon mahasiswa positif yaitu persentase mahasiswa yang memberikan respon positif lebih besar atau sama dengan $80 \%$. Hasil uji coba diperoleh persentase respon mahasiswa pada uji coba kelompok kecil yaitu $84,6 \%$. Sedangkan persentase respon mahasiswa pada uji coba kelompok besar yaitu 85,4\%. Berdasarkan kriteria yang ditetapkan, diperoleh kesimpulan bahwa respon mahasiswa kategori positif.

Berdasarkan tinjauan dari tiga aspek di atas, sehingga dapat disimpulkan bahwa buku ajar pembelajaran matematika ekonomi berbasis problem based learning untuk mengembangkan HOTS pada kriteria valid, praktis dan efektif. Hal ini menunjukkan buku ajar pembelajaran matematika ekonomi yang dikembangkan layak digunakan dalam pembelajaran matematika. Hal tersebut sesuai dengan yang dikemukakan oleh Nieveen (1999: 127) menyebutkan bahwa aspek mutu bahan pertimbangan bahan ajarpembelajaran harus memperhatikan tiga aspek, yaitu: kevalidan, kepraktisan, dan keefektifan.

\section{KESIMPULAN}

1. Buku ajar matematika ekonomi pembelajaran memenuhi kriteria valid, persentase rataan skor hasil validasi (SV) dari kedua validator tersebut yaitu sebesar $83,5 \%$, sedangkan persentase rataan skor hasil validasi (SV) dari validator untuk instrumen yaitu $82,8 \%$. Buku ajar matematika ekonomi pembelajaran memenuhi kriteria praktis, dilihat dari tingkat keterlaksanaan Buku ajar matematika ekonomi pembelajaran yang telah memenuhi kriteria baik.

2. Buku ajar matematika ekonomi pembelajaran juga memenuhi kriteria efektif diperoleh dari hasil ujicoba lembar observasi aktivitas mahasiswa yang memenuhi kriteria baik yaitu sebesar $85,6 \%$, hasil uji coba tes higher order thingking skills sebesar $84,2 \%$ dari keseluruhan mahasiswatelah memenuhi kriteria ketuntasan klasikal, respon mahasiswapositif berdasarkan angket respon mahasiswa yaitu sebesar 85,4\%.

\section{DAFTAR PUSTAKA}

Brookhart, S.M. (2010). How to assess higher order thinking skills in your classroom. Alexandria: ASCD.

Conklin, W. (2012).Higher order thinking skills to develop 21st century learners. Huntington Beach, CA: Shell Education Publishing,Inc.

Depdiknas.(2008). Panduan Pengembangan Bahan Ajar.Departemen Pendidikan Nasional Direktorat Jenderal Manajemen Pendidikan Dasar dan Menengah.

Farren, M. (2012). Using an inquiry-based learning (IBL) approach to encourage higher order thinking among my students of mathematics?.Education and Training Management (eLearning), Dublin City University. Diambil pada tanggal 15 februari 2017 pada: http://www.margaretfarren.net/pasttheses/2011/CaitrionaRooney.pdf

Fogarty, R. (2010). Problem based learning \& kurikulum models for the multiple intelligences classroom. Glenview: Pearson SkyLight 
Miller, M.D., Linn, R.L., \& Gronlund, N.E. (2009).Measurement and assessment in teaching.Upper Saddle River: Pearson Education, Inc.

Moore, K.D. (2009). Effective instructional strategies from theory to practice, Thousand Oaks, CA: SAGA Publications.

Nieveen, N. (1999). Design approaches and tools in education and training. Dordrecht: ICO Cluwer academic publisher.

Widodo, T \& Kadarwati, S. (2013). Higher order thinking berbasis pemecahanmasalah untuk meningkatkan hasil belajar berorientasi pembentukan karakter siswa.Cakrawala Pendidikan, XXXII, 161-171 